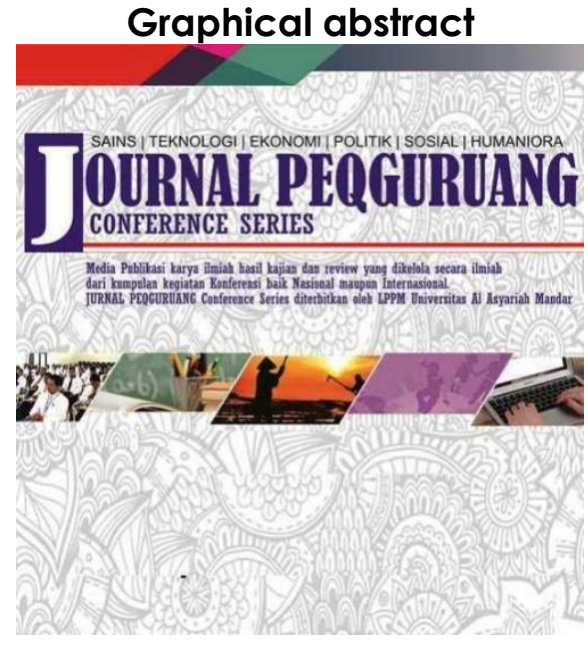

\title{
MENGUPAYAKAN PENINGKATAN KUALITAS APARAT DESA DALAM PENGELOLAAN ADMINISTRASI PEMERINTAH DI DESA MALIMBONG KECAMATAN SESENAPADANG KABUPATEN MAMASA
}

\author{
${ }^{1 *}$ Leonard, ${ }^{2}$ H. Mukhlis Hannan, ${ }^{3}$ Abdul khalik \\ Program Ilmu Pemerintahan, Fakultas Pemerintahan, \\ Universitas Al Asyariah Mandar
}

\section{Corresponding email \\ leonarajaa@gmail.com}

\begin{abstract}
Government administration plays an important role because of the large government involvement in the development process in the administration system. For this reason, so that development goals can truly be achieved as expected, what must be considered is the presence of government officials that have adequate quality. The research location in this study was chosen on the grounds that there is still a lack of effort in improving the quality of administration. To realize research that begins with this interest, a way to make it happen is to choose a method that fits the purpose of a research. The research method in this case serves to answer the issues raised in the study. In order to answer and find solutions to problems in this study, this study uses a qualitative approach to produce descriptive data in the form of written or oral words from people and observed behavior. The results of this study explain that efforts to increase the ability of village officials in carrying out the task of recognizing the village of Malimbong Kemenatan Sesenapandang Mamasa district have been carried out using two approaches, among others, increasing the work discipline of village officials and carrying out education and training. Because of the stipulation in working hours of entering the office, it has a big influence with other disciplines. Forms of education made in the process of aiming towards a better direction like what is aspired by all institutions as well as village organizations in the village of Malimbong Kemacatan Sesenapandang.

Keywords: Efforts, Quality Improvement, Village Administration Services
\end{abstract}

\begin{abstract}
Abstrak
Administrasi pemerintah memegang peranan yang penting karena keterlibatan pemerintah yang besar pada proses pembangunan dalam system administrasi. Untuk itu agar tujuan pembangunan benar-benar dapat tercapai seperti yang diharapkan, maka yang harus diperhatikan adalah adanya aparat pemerintah yang memiliki kualitas yang memadai. Lokasi penelitian pada penelitian ini dipilih dengan alasan karena masih kurangnya upaya dalam peningkatan kualitas administrasi. Untuk mewujudkan penelitian yang berawal dari minat tersebut dilakukanlah cara untuk mewujudkannya adalah dengan memilih metode yang cocok dengan tujuan suatu penelitian. Metode penelitian dalam hal ini berfungsi menjawab permasalahan yang diangkat dalam penelitian. Guna menjawab dan mencari pemecahan permasalahan dalam penelitian ini, maka penelitian ini menggunakan pendekatan kualitatif untuk menghasilkan data deskriptif berupa kata-kata tertulis atau lisan dari orang-orang dan perilaku yang diamati. Hasil Penelitian ini menjelaskan bahwa upaya peningkatan kemampuan aparat desa dalam pelaksanaan tugas admitrasi Desa Malimbong Kemacatan Sesenapandang kabupaten Mamasa telah dilaksanakan mengunakan dua pendekatan antara lain peningkatan disiplin kerja aparat desa dan melaksanakan pendidikan dan pelatihan. Karena adanya penetapan dalam waktu jam kerja masuk kantor sangat besar pengaruhnya dengan kedisiplingan yang lain. Bentuk pendidikan yang dibuat dala proses mamajukan tujuan menuju arah yang lebih baik seperti apa yang di cita-citakan oelh semua lembaga begitu juga organisasi desa Desa Malimbong Kemacatan Sesenapandang.

Kata Kunci: Upaya, Peningktan Kualitas, Pelayanan Administrasi Desa
\end{abstract}




\section{PENDAHULUAN}

Pembangunan nasional bertujuan untuk mewujudkan masyarakat adil dan makmur, yang pada hakekatnya adalah pembangunan manusia seutuhnya dan masyarakat pada umumnya. Untuk mewujudkan tujuan nasional tersebut, pemerintah telah mencanangkan pembangunan yang tersebar di seluruh pelosok tanah air melalui tahap-tahap yang telah ditetapkan yaitu lima tahun. Untuk menunjang keberhasilan pelaksanaan pembangunan yang telah diprogramkan, perlu didukung oleh aparat pelaksana yang mampu dan terjalinnya hubungan yang serasi antara pemerintah pusat dan pemerintah daerah.

Administrasi pemerintah memegang peranan yang penting karena keterlibatan pemerintah yang besar pada proses pembangunan dalam system administrasi. Untuk itu agar tujuan pembangunan benar-benar dapat tercapai seperti yang diharapkan, maka yang harus diperhatikan adalah adanya aparat pemerintah yang memiliki kualitas yang memadai. Kualitas tersebut selain dilandasi kemampuan dan keterampilan yang memadai juga harus disertai disiplin yang tinggi, sehingga dalam merealisasikan tujuan-tujuan nasional sesuai dengan kebijaksanaan pembangunan yang ditetapkan pemerintah, dengan titik berat pembangunan perlu diarahkan pada masyarakat pedesaan karena sebagian besar penduduk Indonesia bertempat tinggal di pedesaan.

Kebijaksanaan pembangunan bagi seluruh lapisan masyarakat merupakan sasaran utama berdasarkan landasan yang telah ditetapkan dan dilaksanakan demi mencapai tujuan sehingga masyarakat desa dapat tumbuh dan berkembang sesuai dengan kemampuan yang dimiliki. Pada kenyataannya tujuan pembangunan dapat tercapai apabila dimulai dari jajaran terendah yaitu pembangunan di tingkat desa (Sunarno Siswanto, 2008).

Oleh karena itu diperlukan aparat pelaksana yang mampu memahami, mengkaji dan menelaah serta menyelesaikan permasalahan yang timbul, sebagai konsekuensi logis dari pada usaha penyempurnaan aparat pemerintahan maka akan dapat menambah kemampuan aparat pemerintah dalam melakukan fungsi perencanaan, pelaksanaan dan pengawasan. Tingkat kemampuan dan keterampilan aparat desa belum memenuhi keinginan yang diharapkan sesuai dengan tingkat perkembangan pembangunan, pengaturan dan penyelenggaraan pemerintahan desa. Sesuai dengan sifat NKRI makan kedudukan desa diseragamkan dan mengidahkan keragaman keadaaan desa dan adat istiadat yang masih berlaku dengan memperhatikan hal tersebut maka desa tidak kehilangan ciri khas desa.

Untuk menyelenggarakan administrasi desa yang efektif diperlukan pembinaan dan pengawasan yang dilakukan oleh pemerintah kecamatan terhadap aparat pemerintah desa dalam bidang pemerintahan, sehingga perangkat desa dapat melakukan tugas dan kewajibannya dengan baik dalam melayani masyarakat.
Hal tersebut diatur dalam Pasal 6 ayat 3 Peraturan Menteri Dalam Negeri Nomor 32 Tahun 2006 tentang Pedoman Administrasi Desa, yang menjelaskan tentang bebagai jenis pembinaan danpengawasan. Pembinaan administrasi desa yang dijalankan adalah untuk mengembangkan system administrasi pemerintahan desa yang berfungsi sebagai sumber data dan informasi bagi seluruh aktifitas pemerintahan dalam pembangunan secara nasional. Untuk meningkatkan manajemen pemerintahan desa perlu dilakukan penataan administrasi agar lebih efektif dan efisien, penataan administrasi merupakan pencatatan data dan informasi dalam mendukung penyelenggaraan pemerintahan desa maka dilakukan penyempurnaan terhadap pelaksanaan administrasi. Oleh karena itu pemerintah kecamatan sangat dituntut untuk turut berperan aktif dalam usaha pembinaan dan pengawasan administrasi yang dilakukan untuk aparat pemerintah desa, sehingga akan terwujud pelaksanaan administrasi yang tertib dandapat mendorong pelaksanaan pemerintahan di wilayah pedesaan.

Dalam penyelenggaraan pemerintahannya Kades (kepala desa) dibantu oleh perangkat desa Dengan pembinaan dan pengawasan administrasi desa pemerintah desa berharap dapat meningkatkan kesejahteraan masyarakat dan mendukung penyelenggaraan pemerintahan desa.

Dari hasil Observasi awal yang dilakukan maka peneliti menemukan beberapa masalah di Desa Malimbong antara lain; sarana dan prasarana yang kurang memadai, kurangnya pengetahuan masyarakat, sumber daya manusia (SDM), konflik kepentingan pribadi dan masih kurangnya melakukan pembinaan dan pengawasan dalam bidang administrasi desa.

Berdasarkan latar belakang dari permasalahan di atas, peneliti tertarik untuk mengetahui lebih mendalam mengenai permasalahan yang sebenarnya tentang peningkatan sumber daya manusia dalam hal ini adalah aparat desa dalam pelaksanaan tugas administrasi desa. Sehingga dalam penelitian ini. judul yang diambil oleh peneliti adalah: Upaya Peningkatan Kemampuan Aparat Desa dalam Pelaksanaan Tugas Administrasi di Kantor Desa Malimbong Kecamatan mamsa Kabupaten Mamasa.

\section{METODE PENELITIAN}

Penelitian ini dipilih dengan alasan karena masih kurangnya upaya dalam peningkatan kualitas administrasi desa yaitu Desa Malimbong Kecamatan Serena Pandang Kabupaten Mamasa, Waktu penelitian mulai pada bulan Febuari sampai bulan April Tahun 2020

Penelitian ini lakukan dengan metode kualitatif, guna menjawab dan mencari pemecahan permasalahan dalam penelitian ini. Selain itu pula peneliti menggunakan teknik sampling yang digunakan ketika peneliti mempunyai pertimbangan-pertimbangan tertentu dalam pengambilan sampelnya (Arikunto, 2009:128). Menurut peneliti informan dalam penelitian ini adalah: 
a. Kepala Desa Malimbong: 1 Orang

b. Sekretaris Desa Malimbong: 1 Orang

c. Kepala Urusan: 3 Orang

d. Perwakilan Kepala Dusun: Orang 2 orang

e. Masyarakat: 2 Orang

Dalam penelitian ini menggunakan metode observasi wawancara dan dokumentasi. Oleh sebab itu, instrument yang dibutuhkan adalah pedoman observasi, pedoman wawancara, kamera serta alat tulis. Instrument pada penelitia ini adalah peneliti itu sendiri yang disertai alat bantu berupa kamera. Dalam penelitian kualitatif, peniliti mempunyai kedudukan sebagai perencana, pelaksana pengumpul data, analisis, penafsiran, dan sebagai pelapor hasil peneliti.

\section{HASIL DAN PEMBAHASAN}

\section{Gambaran Umum Lokasi Penelitian}

Struktur Organisasi Komisi Pemilihan Umum

Gamabaran umum Desa Malimbong Kemacatan Sesenapandang Desa Malimbong Kecamatan sesenapandang merupakan Daerah yang memiliki wilayah daerah $18,14 \mathrm{Km}^{2}$. yang letak georafinya dibatasi oleh: sebelah utara kelurahan messawa dan desa rmppung, sebelah timur berbatasan dangan kabupaten tanah toraja, dan diseblah selatan a berbatasan dengan desa matande, sebalah barat berbatasan dengan desa Makua. Memliki jumlah penduduk sebanyak 701 jiwa dari luas wailayah b. disebutkan, sangat banyak sesuatu yang bisa digunakan oleh penduduk sebaga tanah produktif, c. diantaranya Ladang, Sawah, Kebun Kopi dan lainnya. Jumlah penduduk yang sekarang ini ada berada pada desa malimbong dapat dilihan pada tabel berikut:

Tabel 1 Penduduk Desa Malimbong Kecamatan Mamasa

\begin{tabular}{|l|l|}
\hline Jenis Kelamin & $\begin{array}{l}\text { Jumlah } \\
\text { Penduduk }\end{array}$ \\
\hline Pria & 332 \\
\hline Wanita & 369 \\
\hline Jumlah & 701 \\
\hline
\end{tabular}

Saran Umum

Penggunaan Listrik: 81 (PLN), 111 (Non PLN) 13 lainya, Banyaknya Sekolah: SD (2), Fasilitas Kesehatan: Pustu 1, Posyandu , tempat ibadah memiliki 3 gerejah.

\section{Pembahasan}

Bentuk Kinerja Aparat di Desa Malimbong Kecamatan sesenapandang Kabupaten Mamasa.

Kebradaan aparat desa yang juga diserahi tugas dibidang admistrasi, menduduki posisi yang sangat penting karena sebgai organ pemerintahan yang baling bawah mengetahui secara pasti mengenai kondisi dan permasalahan yang ada diwilayahnya, maka input pada pemerintahan kebijaksanaan daerah maupun nasional untuk kebutuhan pembangunan secaralah menyeluruh.
Upaya peningkatan kinerja aparat desa didesa malimbong dalam pelaksanaan tugas andministrasi pemerintahan khusunya administrasi pemerintahan desa yang meliputi: Pembinaan disiplin pegawai, pendidikan dan pelatihan, motivasi kerja, dan pengembangan karisma. Upaya peningkatan kinerja dalam kemampuan aparat desa disebabkan oleh kondisi pelaksanaan tugas pemerintahan desa disebabkan oleh beberapa paktor yang melingkupi aparat desa di desa malimbong.

\section{Pelaksanaan Pemerintahan.}

Pada pelaksanaan pemerintahan desa malimbong terdiri dari Kepala desa, lembaga kemasyarakatan, dan di dampingi oleh sekertaris desa, para kepala dusun, dan kepala RT. Sekertasi desa malimbong pada tugasnya didampingi oleh beberapa urusan antara lain, Kaur, Pemerintahan, Kaur Pembangunan, dan Kaur Umum.

Diluar dari pada sekertari dan kaur, kepala desa juga tidak terhidar dari bantuan para pemukan agama, toko dadt, juga tokoh msyarakat desa malimbong yang selalu ikut sereta dalam menjalankan pemerintahan. Selain dari pemerintahan yang disebutkn diatas, yang dijadikan program desa pada desa malimbong adalah sebagai berikut:

Mendukung generasi muda agar terciptanya manusia yang mampu manjawab persoalan dan pada umumnyabertanggung jawab bagi bangsa dan negara.

Mendukung agar masyarakat selalu akatif diberbagai bidang seni dan budaya.

Menumbuhkan semangat kebersamaan demi pembangunan desa malimbong sehat bersi dan indah

\section{Tugas Pokok Keorganisasian.}

Pemerintah desa dalam hal ini kepala desa alah pemimpin atau pemengang kekuasaan ditingkat desa yang dimana dipilih lang oleh msyarakta desa.

Susunan organisis pada kator desa malimbong yalah kepala desa dan juga jajaranya. Antara lain. Sekertaris Desa, dan di bantu oleh bagian-bagian antara lain: 1. Bagian Pemerintahan, 2. Bagian Pembangunan, 3. Bagian kemasyarakatan, 4. Bagian pelayanan umum,dan 5. Bagian keuangan.

Menurut para ahli dikatakan kalu arti dari organisasi yalah struktur tata pembagian kerja dna stuktural tata hubungan kerja antara kelompok orang yang memliki penganan juga menerangkan tupoksinya. Dalam menjalankan tugasnya wajib melakukan hubungan yang baik melalui suatu aplikasi demi mancapai sutu tujaan yang sama. Merujuku pda apa yang telah dijelaskan tersebut, dapat disimpulkan bahwa dalam menjalankan roda pemerintahan ditingkat desa/kelurahan memerlukan beberapa hala antalain:

1. Struktur organisasi pemerintah dsa

2. Pembagian tufoksi masing tugas

3. Megatur penyusunan pelaksan dan staf

4. Mengatru hubungan kerja sama oantara organisasi dengan organisasi lainya demi memliki hubungan bersama.

Pada UUd 1945 sudah dijelaskan dengan baik dan bisa diartikan sebagai bahwa fungsi desa sebgai organisasi pemerintahan secara efesien. Demi mencapai 
kepemimpinan desa di rumuskan desnga cara sedehana dan lebih baik supaya gampang menyesuaikan dengan apa yang menjadi kebutuhan pada masyarakta dengan tetap memperhatiakan norma2 yang ada secara umum.

Dalam ketetapan UU No. 32 tahun 2004 telah deijalskan bebrapa hal sebgai berikut:

1. Pemerintah desa terdidi atas kepala desa dan perangkat desa.

2. Perangkat desa terdiri dari sekertaris, dan perangkat lainya.

3. Sekertaris desa yang dimaksud dalam ayat 2 yang isian dari pegawai ngeri sipil yang mematuhi syarat

Pada usaha mengoptimalisasikan pelayanan terhadap masyarakat pada bdang admistrasi dan bagianurusan pemerintahan, maka pada bagian desa malimbong kecamatan mamasa kabupaten mamasa di dukung dari perangkat desa pada hubungan kelembangaan desa. Berikut bagang struktur organisasi desa malimbong

\section{SUSUNAN ORGANISASI PEMERINTAH DESA.}

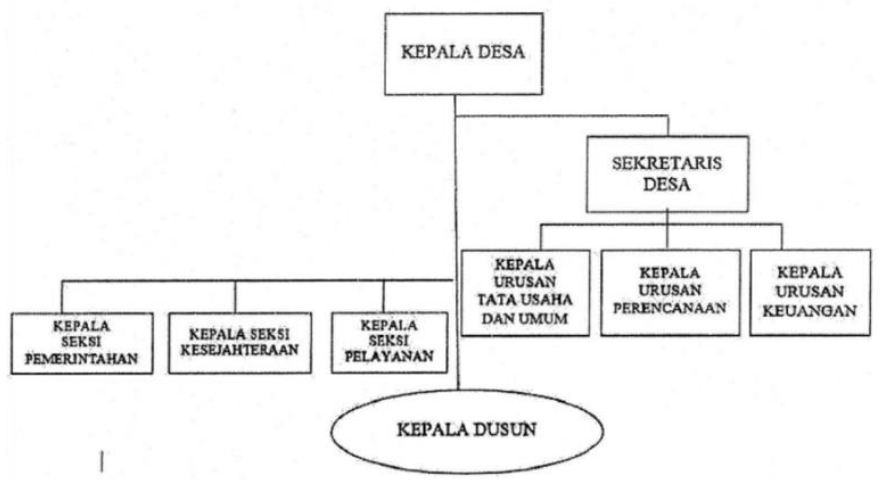

Gambar 1. Struktur organisasi desa malimbong

Mengasu pada gambar struktur organisasi diatas. Dapat digambarkan mengenai tugas pokok dari semua baigai-bagiannya. Berikut keterangan mengenai bagianmagian yang dimasud:

1. Funsi dan tugas pokok kepala desa.

2. Fungsi dan tugas usaha kepala desa

3. Tugas Pokok dan bagian ketertiban

4. Ugas pokok dan fungsi seksi pembangunan

5. Tugas pokok danfungsi bagian kesejahteraan rakyat

\section{Upaya peningkatan Kemampuan Perangkat Desa Pembinaan disiplin perangkat desa.}

Upaya yang bisa dilaksanakan dalam peningkatan pemberdayaan yang efisiensi dlam perkerjaan pengawai negeri sipil dalam menjalankan tugas dan kewajibanya yalah dengan pembinaan displin, agar supaya pengawai pada saat melaksanakan tugasnya setiap harinya selalu taat dan patuh pda apa yang menjadi ketentuan yangsudah ditetapkan demi mencapai kinreja yang maksimal. Selajanya dengan penelitian yang dilakukan, peneliti mngdalami informasi dengan melaksanakan wawancara langsung pada ornga yang menjadi narasumber dan di setiap narasumber yang peneliti tentukan, peneliti menyampaikan pertanyaan antara lain:

Pengembangan Keterampilan

Kegiatan yang dilakukan dlam persediaan sumberdaya perangkatdesa yang yang baik sangat di upayakan disebabkan dengan adanya tanggung jawab pemerintah dalm membelirkanpelayanan terhada apa yang dibutuhkan masyarakat, selai dengan karna diharuskanya untuk mengetahui kebutuhan aparat desa dangan sumberdaya manusia yang mempunyai kemampuan sesuai dangan tugas penyelenggaraan peda kegiatan pemerintahan. Dan menjadi sanga orjen dalam memahami terhada apa saja yang menjadi komposisi dalam keperluan untuk mencapainya tujuan pelyanan terhadap masyarakat.

Dalam menguasai suberdaya manusia yang mampunyai kapabilitas untuk melaksanakan tugas admistrasi pemerintah dalam melaksanakan kegiatan pemerintah, sangat diperlukan bergai informasi mengenai kompoenis yang orjen dalam melaksanakan suatu kegiatan baik dalam kapasitas yang memenuhi keinerja yang lebih bagus.

Keterampilan fungsional debdakan dari keterampilan dasar (Enabling Skill) yang merupakan hal-hal mendasar yang harus dimiliki seseorang, yang kemudian dikembangkan secara lebih spesifik sehingga berfungsi dalam keterampilan fungsional. Enabling skill terdiri dari: membaca, menulis, matematika dasar dan lain-lain, yang semuanya itu perlu dipertajam dan digabungkan untuk menjadi keterampilan yang efektif.

Desa Malimbong Kecamatan Mamasa Kabupaten Mamasa dalam penelitian ini, maka peneliti menggali informasi mengenai hal tersebut dengan melakukan wawancara dengan narasumber yang telah upaya peningkatan kemampuan aparatur desa dalam pelaksanaan tugas administrasi di Kantor Desa Malimbong.

Program Pendidikan dan Pelatihan

Untuk keberhasilan penyelenggaran pendidikan dan pelatihan ditentukan oleh berbagai macam faktor antara lain penentuan tujuan pendidikan dan pelatihan, pengambangan pengetahuan dan ketemapilan, penyusunan proram, dan pelatihan, penyelenggaraan administrasi dan keuangan, proses pembalajaran fisik, serta lingkungan emosional, faktor-faktor tersebut menunjang efektivitas dan efesiensi penyelenggaraan pendidikan dan pelatihan, apabila berada dalam rangka sistem. Dengan kata lain dapat dikatakan sebagai faktor yang menentukan keberhasilan pendidikan dan pelatihan adalah sistem penyelenggaraan pendidikan dan pelatihan itegral, dimana sub sistem dari sistem tersebut terkait satu dengan lainnya.

Berdasarkan peraturan Kepala Lembaga Adminsitrasi Negara nomor 02 tahun 2008 tentang akreditasi pendidikan dan pelatihan pemerintah, ada beberapa unsur yang menjadi penilaian lembaga pendidikan dan pelatihan yaitu tenaga kediklatan, progra, diklat, fasilitas diklat, ketiga unsur tersebut 
dijabarkan sebagai berikut ; tenaga kediklatan, program pendidikan dan pelatihan fasiliatas pendidikan dan pelatihan.

Pendidikan dan pelatihan memiliki peran strategis untuk meningkatkan kualitas sumber daya aparatur yaitu aparatur pegawai yang propfesional baik dalam hal kompetensi, sikap dan prilaku yang diharapkan sesuai dengan tugas dan peranannya masing-masing.

Untuk dapat meningkatkan kualiatas aparatur pegawai yang kreatif, profesional dan menjunjung tinggi prinsip-prinsip pemerintahan yang baik serta bebas KKN,

Pendidikan dan pelatihan didefinisikan sebagai usaha yang terencana dari organisasi untuk meningkatkan pengetahuan, keterampilan, dan kemampuan aparat desa yang terdapat beberapa keuntungan dengan melakukan program pendidikan dan pelatihan bagi apaarat desa yang pada akhirnya akan membawa keuntungan bagi organisasi diantaranya:

$\checkmark$ Mendorong pencapaian pengembangan diri bagi aparat desa.

$\checkmark$ Memberikan kesempatan bagi pegawai untuk berkembang dan memiliki pendangan tentang masa depan dan karirnya

$\checkmark$ Membantu staf atau peagawai dalam menangani konflik dan ketegangan.

$\checkmark \quad$ Meningkatkan kepuasan kerja dan prestasi kerja

$\checkmark$ Menjadi jalan perbaikan keterampilan dalam bersosialisasi dan berkomunikasi.

$\checkmark$ Membatu menghilangkan ketakuatan dalam mencoba hal-hal dalam pekerjaan.

$\checkmark$ Menggerakkan pegawai untuk mencapai tujuantujuan organisasi.

Berdasarkan hal-hal diatas maka pendidikan dan pelatiahan memberikan dampak yang baik terhadap kinerja pegawai tersebut sebagai individu. Hal ini jelas akan membawa peningkatan terhadap kinerja organisasi apabila pendidikan dan pelatihan pegawai dilakukan secara terencana dan berkesinambungan.

Pendidikan dan pelatihan aparat desa yang berbasis kompetensi dapat membantu organisasin khususnya pemerintah desa untuk memiliki SDM yang kompeten dan handal dalam bekerja. Melalui berbagai kegiatan pendidikan dan pelatihan, kompetensi SDM akan lebih optimal dan berujung pada meningkatnya kinerja organisasi melalui penjabaran dan serta operasional dengan visi dan misi.

Kebijakan pengembangan sumbe rdaya Perangkat Desa selain bertujuan meningkatkan wawasan Perangkat Desaur sebagai abdi negara dan abdi masyarakat dalam ukuran yang seimbang, juga meningkatkan profesionalisme agar pegawai negeri sipil lebih aktif dan efisien. Untuk itu pengembangan sumber daya Perangkat Desaur perlu dilakukan, karena dengan kegiatan tersebut akan terjadi peningkatan kemampuan pegawai, baik kemampuan profesionalnya, kemampuan wawasannya, kemampuan kepemimpinannya maupun kemampuan pengabdiannya.

Peningkatan Pengalaman kerja
Menurut manulang pengalaman kerja adalah proses pembentukanpengetahuan dan keterampilan tentang metode peningkatan suatu pekerjaan bagi para pegawai karena keterlibatan tersebut dalam pelaksanaan pekerjaannya. Indikator dan alat ukur yang digunakan dalam penelitian ini meliputi jangka waktu pengalaman kerja bidang keuangan.

Pengalaman dan pendidikan sering digunakan secara bersamaan karena kombinasi antara pengalaman dan pendidikan dapat menciptakan yang dilakukan dengan cara menampilkan kosuoner dari aparatur desa malimbong

Kebiasaan pada saat kerja merupakan pembuatan ilmu atau keahlian mengenai suatu cara pekerjaan karena ikut serta pada staf tersebut pada pelaksanaan tugas kegiatan terdapat istilah yang mengemukakan bahwa pengalaman yalah guru yang paling baik, seorang sseorang guru yang mampu menatarkan seseorang kemasa depan yang gemilang. Apabila tidak adanya pengalaman maka tidak akan mampu menguku bahawa sejauh mana kemampua yang kita miliki. Akan tetapi karena pangalaman ilah kita akan mampu hidup lebih baik dari yang sebelumnya dan mamapu menganalisis pada suatu kegiatan yangakan kita lakukan.

\section{Pelaksanaan Tugas Adiministrasi Pemerintahan Desa}

Administrasi pemerintaha desa yalah merupakan keseluruhan proses kegiatan pencatatan data dan informasi mengenai pemerintahan desa pada buku register desa

Penyelnggaraan admnistrasi pemerintahan desa dilakukan melalui:

Tertib pencatatan data dan infomasi dalam buku register desa

Pengembangan buku register desa yang diperlukan serta menyelnggarakan pelaporan sesuai ketentuan perundang-udangan.

Penyelnggaraan dan pengembangan administrasi pemerintahan desa melalui tertib pencatatan data dan pengembangan buku register desa yang disesuaikan dengan kebutuhan, tingkat pemerintah desa, dan kopleksitas permasalahan yang dihadapi didalam pencatatan data dan informasi bergai kegiatan

Kegiatan pecatatan data dan informasi mengenai kegiatan-kegiatan pemrintahan desa yang dimuat dalam administrasi umum, andministrasi umum yang dimaksud meliputi:

$\checkmark \quad$ Buku peraturan didesa.

$\checkmark \quad$ Buku keputusan kepala desa

$\checkmark \quad$ Buku inpentaris dan kelayakan desa

$\checkmark \quad$ Buku aparat pemerintah desa

$\checkmark$ Buku tana kahs desa

$\checkmark \quad$ Buku tanah didesa

$\checkmark \quad$ Buku agenda

$\checkmark \quad$ Buku spedisi

$\checkmark \quad$ Buku lembaran desa, dan

$\checkmark \quad$ Buku berita desa

Bentuk dantata cara pengisian buku administrasi umum sebagai mana dimaksud pada ayat 2 tercantu 
dalam lampiran yang merupakan bagian yang tidak terpisahkan dari peraturan pemerintah.

Pencatatan atau Registrasi

Register adalah suatu aktivitas pemerintahan dengan maksud untuk mendokumentasikan berbagai peristiwa dan atau kegiatan yang telah terjadi melalui pencatatan-pencatatan di dalam format yang telah ditetapkan.

Daftar register dalam penyelenggaraan pemerintahan pada tingkat dalam hingga sekarang ini yang digunakan di Desa Malimbong adalah berdasarkan pada Kepmendagri Nomor 414.3/316/PMD/2003, tentang Register Dalam. Dalam Keputusan tersebut, ditetapkan adanya tiga jenis buku yang terdiri dari (1). Buku Administrasi Umum, meliputi Buku Kekayaan dan inventaris dalam, buku tanah, buku keputusan dalam dan buku agenda; (2). Buku Administrasi Penduduk, meliputi Buku Induk Penduduk dan Buku Rekapitulasi Penduduk Akhir Bulan (3). Buku Administrasi Keuangan meliputi Buku Kas Umum dan Buku Kas Pembantu.

Belum optimalnya kuliatas dan kinerja pemrintah secara garis besar disebabkan oleh banyak faktor yaitu rendahnya kurang sumber daya manusia dari aparat pemerintah desa, sumber daya dan potensi keuangan sebagai sumber pendapatan desa masih terbatas baik karena minimnya sumber maupun ketidakjelasan alokasi dana dari pemerintah desa.

Melaksanakan urusan keuangan seperti pengurusan administrasi keuangan, administrasi sumber-sumber pendapatan dan pengeluaran, verifikasi administrasi keuangan, dan administrasi keuangan, dan administrasi penghasilan kepala desa, perangkat desa, BPD, dan lembaga pemerintah desa.

\section{KESIMPULAN}

Mangacu pada hasil penelitian, peneliti mangambil kesimpulan kalau dalam upaya peningkatan kemampuan aparatur desa dalam pelaksanaan tugas admitrasi Desa Malimbong Kemacatan Sesenapandang kabupaten mamasa telah dilaksanakan mengunakan dua pendekatan antaralain peningkatan disiplin kerja Aparat desa dan juga malaksanakan pendidikan dan pelatihan. Yang menjadi bentuk pelaksanaan disiplin waktu pada jam kerja,

Karena adanya penetapan dalam waktu jam kerja masuk kantor sangat besar pengaruhnya denga kedisiplingan yang lain. Bentuk pendidikan yang dibuat dala proses mamajukan tujuan menuju arah yang lebih baik seperti apa yang di cita-citakan oleh semua lembaga kemampuan bertujuan kearah yang diinginkan oleh organisasi desa Desa Malimbong Kemacatan Sesenapandang.

Akan tetapi pelatihan yalah sebuah proses pendidikan yalah merupakan suatu keniscayaan dalam meningkatkan kapasitas pada suatu individu maupun kelompok.

Mengacu pada apa yang dihasil kan oleh peneliti sebagai berikut:
Dalam upaya peningkatan yang kemampuan pemerintah desa dalam pelaksanaan tugas admitrasi pemerintah yalah:

$\checkmark$ Melakukan pembinaan disiplin waktu terhadap aparatur desa. agar segala sesuatunya mengenai dengan kegaitan atrau keawjibannya dapat dijalankan dengan baik.

$\checkmark$ Pendidikan dan pelatihan. Dengan melakukan pendidikan danjuga pelatihan makan dengan sendirinya segala apa yang akan dikerjakan akan lebih baik dan efektif.

\section{DAFTAR PUSTAKA}

Arikunto, S.2009. Prosedur Penelitian Suatu Pendekatan Praktik. Edisi Revisi 6. Jakarta: Rineka Cipta.

Anonim, Undang-Undang Nomor 32 Tahun 2004 Tentang Pemerintahan Daerah. Dharma Bhakti. Jakarta

Anonim, Instruksi Mendagri Nomor 21 Tahun 1992 tentang Pedoman Pelaksanaan Pemerintahan Daerah, Setneg, Jakarta

Badan Penelitian dan Pengembangan Kota Medan. 2012. Analisis Kemampuan Kerja Aparat Kecamatan Dalam Memberikan Pelayanan Administrasi Kepada Masyarakat.

Candra Kusuma Putra, Ratih Nur Pratiwi, suwondo, Pengelolaan Alokasi Dana Desa Dalam Pemberdayaan Masyarakat Desa dalam Pemberdayaan Masyarakat Desa. Jurnal Administrasi Publik, vol I, No. 6.

Handoko, H. 2006. Manajemen Personalia dan Sumber Daya Manusia.Yogyakarta: BFFE.

Hasibuan, Malayu. 2007.Manajemen Sumber Daya Manusia,cetakan kesembilan. Jakarta: PT Bumi Aksara

HR, Ridwan. 2014. Hukum Administrasi Negara, Jakarta: Raja Grafindo Persada

I Nyoman Beratha, Masyarakat Desa dan Pembangunan Desa. Jakarta: Ghalia Indonesia, 1982.

Karim, Muhammad. Pemimpin Transformasional di Lembaga Pendidikan Islam. Malang: UIN Maliki Malang Press, 2010.

Kamus Besar Bahasa Indonesia, Medan: Bitra Indonesia, 2013. Hlm.2.

Kartono, Kartini. 2012. Pemimpin dan Kepemimpinan: Apakah Kepemimpinan. Abnormal Itu-Ed. 1,Cet, 18-. Jakarta: Rajawali Pers.

Kutai Timur.E-Journal Ilmu Pemerintahan. 2013, Vol 1 No 3.

Moleong, Lexy J. 2009.Metodologi Penelitian Kualitatif. Bandung: PT Remaja Rosdakarya Offset.

Miles, Mathew B dan Huberman. Analisis Data Kualitatif. Jakarta: Universitas Indonesia Press, 1992.

Nuji. 2013. Fungsi Camat dalam Pembinaan Penyelenggaraan Pemerintahan Desa di Desa Muara Bengkal Kecamatan Muara Bengkal Kabupaten 
Peraturan Pemerintah Nomor 72 Tahun 2005 Tentang Desa.

Permendagri Nomor 84 Tahun 2015 tentang Susunan Organisasi dan Tata Kerja Pemerintah Desa (SOTK) mulai dari Pasal 6 sampai Pasal 10 di sebutkan bahwa, Kepala Desa dan Perangkat desa mempunyai Tugas dan Fungsi

Peraturan Pemerintah Nomor 72 Tahun 2005 Tentang Desa, penjelasan mengenai Desa.

Peraturan Pemerintah menganai undang-undang Nomor 6 Tahun 2014 tentang Desa.

Ridwan,Juniarso dan Achmad Sodik Sudrajat.2014.Hukum Administrasi Negara dan Kebijakan Pelayanan Publik.Bandung:Nuansa Cendikia

Rahman, Reza.2009.Corporate Social Responsibility Antara Teori dan.Kenyataan. Jakarta: PT. Buku ita.

Widjaja ,A. W. 2012. Administrasi Kepegawaian 2. Jakarta: Rineka Cipta

Wastiono, Sadu. 2006. Prospek Pengembangan Desa. Bandung: V.Fokusmedia

http://id.wikipedia.org/wiki/Desa,html (9 Agustus 2017).

http://www.academia.edu/11080401/Asas_Penyelenggara an_Pemerintahan_Desa_Berdasarkan_UU_DES A.html,(10 Agustus 2017).

http://politik.kompasiana.com/2014/09/16/otonomidaerah-dalampembangunan--688380.html,(10 Agustus 2017) 